\title{
ECONOMIC VALUATION OF MANGROVE FOREST IN THE EAST COAST OF THE CITY OF SURABAYA, EAST JAVA PROVINCE, INDONESIA \\ Deni Kusumawardani*
}

${ }^{*}$ Department of Economics, Faculty of Economics and Business, Universitas Airlangga, Indonesia

\begin{abstract}
The city of Surabaya has been voted as one of the pilot areas of mangrove forest conservation in ASEAN. Most of the mangrove forest area in the city of Surabaya spread across the East Coast (Pamurbaya). The purpose of this study is to estimate the total economic value of mangrove forests in the area as a source of information for planning and evaluation of conservation policy. The results of the valuation involving some valuation techiques, both market and non-market approaches, yield total economic value of about $R p$ 49.6 billion (US\$ 3.8 million) per year, or 105.3 million (US\$ 8,101.8) per ha per year. Almost all of these values is the use value, particularly direct use valule both extractive (timber and fisheries) and non extractive (outdoor recreation). Indirect use value which consists of abrasion barrier and carbon sinks contributed relatively small compared to the direct use value. Meanwhile, non-use value is the smallest contributors to the total economic value. This fact proves that the mangrove forest in Pamurbaya has economic benefits outweigh the ecological benefits.
\end{abstract}

Keywords: Economic Valuation, Mangrove, Non-Market Approach, The City of Surabaya

\section{JEL Classification: A130, D78}

To cite this document: Kusumawardani, Deni (2019). Economic Valuation Of Mangrove Forest in The East Coast Of The City Of Surabaya, East Java Province, Indonesia. JDE (Journal of Developing Economies), 4 (1), 53-62

\section{Introduction}

Indonesia is one of the countries with the largest mangrove forest in the world. The contribution of Indonesia and four other countries (Australia, Brazil, Nigeria, and Mexico) are about $46.2 \%$ of the total area of world mangrove forests (Food Agriculture Organization - FAO 2010). In a symposium on the development of mangrove forests in ASEAN organized by the Japan International Cooperation Agency (JICA) on 27 February 2013, Indonesia was voted as a pilot country and the two cities in Indonesia selected as pilot areas are city of Surabaya and Balikpapan (Pemerintah Provinsi Jawa Timur, 2013).

It is around $80 \%$ of the mangrove forests in the city of Surabaya located in the East Coast (Pamurbaya) and the rests in the North Coast (Pantura) (Badan Lingkungan Hidup Kota Surabaya, 2012). The Ecological Observation and Wetlands Conservation (ECOTON) in BLH Kota Surabaya (2011)noted that the mangrove forest area in Pamurbaya experienced a sharp decline which was around 3,200 ha in 2002 to 471.15 ha in 2012. The major causes of this phenomenon were traditional business of fishpond and the use of sedimentation area by the local community. If this condition continues, it will reduce the mangrove forest area and cause fragmentation between coastal and river which can cause imbalance function of the

JDE (Journal of Developing Economies) p-ISSN: 2541-1012; e-ISSN: 2528-2018

DOI: http://dx.doi.org/10.20473/jde.v4i1.12853

Open access under a Creative Commons Attribution 4.0 International

(CC-BY)

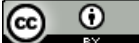


mangrove forest.

Agriculture Agency of the city of Surabaya has takenseveral policies to conserve the mangrove forests in Pamurbaya. Since 2007, the mangrove forest area has been designated as tourist attraction or ecotourism, particularly for outdoor recreation. In addition, it has been issued a regulation that in this area it is prohibited to build housing and create economic activities. Technically, efforts to conserve mangrove forests carried out by reforesting or planting mangrove seedlings at some points that have been deforested under collaborative supervision with sub-districts in Pamurbaya area.

Conservation of mangrove forest and natural resources in general requires information of costs and benefits as a basis for taking and evaluating policies. The benefits of an ecosystem can be known from its ability to provide goods and services for human life and well-being (Vo et al. 2012). Based on these criteria, mangrove forest is known as one of the ecosystems that have high productivity and value, both economically and ecologically (Harahab 2010; Hoberg 2011; Stewart and Fairfull, 2008). However, most services produced by this ecosystem do not have a market price, so the diversity of the benefits is often ignored. A comprehensive assessment of benefits of the mangrove forest needs uniformity in measurement. The measurement that can be used to equalize the perceptions of various experts, especially ecologists and economists, is through price tag expressed by monetary units. This is known aseconomic valuation (Fauzi 2014; Kaval 2010).

The empirical studies of economic valuation of mangrove forests have been carried out in many countries, such as Leong et al (2005) in Malaysia, Sathirathai and Barbier (2001) in Thailand, and Hoberg (2011) in Kenya. In Indonesia a similar study has also been conducted including by Ruitenbeee (1991) in Bintuni Bay, Irian Jaya Province; Harahab (2010) in Kecamatan [sub-district] Gending, Kabupaten [district] Probolinggo; Suzana et al. (2011) in Desa [village] Palaes, Kecamatan Likupang Barat, Kabupaten Minahasa Barat; and Haridhira (2012) in Benoa Bay, Bali Province. These studies resulted diverse values depending on many factors, especially types of the value estimated, and data and methods used. The study of the economic valuation of mangrove forests in Pamurbaya was actually carried out by BAPPEKO Surabaya (2012), but the study has several weaknesses including small sample size, relatively narrow range of economic value types, inappropriate value measures, and valuation methods that are not valid. Consequently, these weaknesses produced undervalued of the economic value compared to similar studies conducted in various other regions or countries. Therefore, this research is intended to revise and expand the study by involving relatively better and completed data and method, so that the values estimated are close to true of total economic value.

\section{Research Design and Method}

This research was carried out in the mangrove forest area in the East Coast of the city of Surabaya (Pamurbaya), East Java Province, Indonesia in 2014. The area of Pamurbaya is about $2,503.9$ ha and around $19 \%$ of it ( $471.15 \mathrm{ha}$ ) is mangrove forest. The mangrove forests in Pamurbaya are scattered in six kelurahan [villages] in four kecamatan [sub-districs] with the following composition: (1) Kelurahan Gunung Anyar Tambak, Kecamatan Gunung Anyar (16\%); (2) Kelurahan Medokan Ayu, Kecamatan Rungkut (19\%), (3) Kelurahan Wonorejo, Kecamatan Rungkut (13\%); (4) Kelurahan Keputih, Kecamatan Sukolilo (21\%), (5) Kelurahan Kalisari, Kecamatan Mulyorejo (21\%); and (6) Kelurahan Kejawan Putih Tambak, Kecamatan Mulyorejo (10\%) (Badan Lingkungan Hidup Kota Surabaya, 2012; BAPPEKO Surabaya, 2012).

The types of data used in this study include both primary data and secondary data. Primary data is obtained through field survey using an in-depth interview method with a questionnaire guide to a number of respondents. The sampling technique used is purposive sampling. Respondents are visitors who made the mangrove ecotourism area as the main recreational destination. The number of respondents interviewed (sample size) is determined based on Slovin formula as follows (Sugiyono, 2012). 


$$
n=\frac{N}{\left(1+N \times e^{2}\right)}
$$

where $\mathrm{n}$ is the minimum sample size, $\mathrm{N}$ is the population size, and e is allowable error. Based on data from Dinas Pertanian Kota Surabaya, the number of visitors to the mangrove forest ecotourism was 24,466 in 2014 . Using e $=0.1$, the minimum sample size is 100 . Meanwhile, secondary data was obtained from Central Bureau of Statistics (BPS), Pemprov Jatim, BAPPEKO, BLH Kota Surabaya, World Bank, and others.

Total economic value (TEV) of the mangrove forests (and other natural resources) is the sum of two main types of values, namely use value (UV) and non-use value (NUV) (Brander et al. 2010; Harahab, 2010; Kaval 2010). The UV consists of direct use value (DUV), indirect use value (IUV), and option value (OV). Meanwhile, NUV includes bequest value (BV) and existence value (EV). In most studies, including Leong (2005) and Haridhira (2012),BV and EV are calculated as a single unit of value from NUV. Referring to these studies, the components of the economic value of the mangrove forests in this study is expressed by equation as follows

$$
T E V=(D U V+I U V+O V)+N U V
$$

According to Kementerian Lingkungan Hidup [The Ministry of Environment] - KLH (2012) the practice of economic valuation of different components of the value of natural resources and environment (NRE) is not easy. Therefore, the calculation of economic value is sufficient for NRE which has the dominant use value with the easiest and most likely approach to be carried out in accordance with the data and the purpose of the calculation. Table 1 presentsthe type of economic value, definitions and measurements, and valuation methods of the mangrove forests used in this study.

Table 1: Types of Economics Value and Valuation Techniques of Mangrove For-

\begin{tabular}{|c|c|c|c|}
\hline Types of Values & Definitions & Measurements & Valuation Techniques \\
\hline \multirow[t]{2}{*}{$\begin{array}{l}\text { Direct Use Value } \\
\text { (DUV) }\end{array}$} & $\begin{array}{l}\text { The value of actual use directly, both } \\
\text { extractive and non-extractive }\end{array}$ & $\begin{array}{l}\text { 1. The value of timber } \\
\text { and fishery (extractive) }\end{array}$ & 1. Market Price \\
\hline & & $\begin{array}{l}\text { 2. The value of outdoor } \\
\text { recreation } \\
\text { (non-extractive) }\end{array}$ & \\
\hline \multirow[t]{2}{*}{$\begin{array}{l}\text { Indirect Use Value } \\
\text { (IUV) }\end{array}$} & $\begin{array}{l}\text { The values related to ecological func- } \\
\text { tions }\end{array}$ & $\begin{array}{l}\text { 1. The value of abrasion } \\
\text { barier service }\end{array}$ & 1. Replacement Cost \\
\hline & & $\begin{array}{l}\text { 2. The value of carbon } \\
\text { sinkservice }\end{array}$ & 2. Benefit Transfer \\
\hline Option Value (OV) & $\begin{array}{l}\text { The value of future use, either direct- } \\
\text { lyor indirectly }\end{array}$ & The value of biodiversity & Benefit Transfer \\
\hline $\begin{array}{l}\text { Non-use Value } \\
\text { (NUV) }\end{array}$ & $\begin{array}{l}\text { The values that are not related to utili- } \\
\text { zation, either directly or indirectly, but } \\
\text { based on individual preferences }\end{array}$ & $\begin{array}{l}\text { The bequest value (BV) dan } \\
\text { the existencevalue (EV) }\end{array}$ & $\begin{array}{l}\text { Contingent Valuation } \\
\text { Method }\end{array}$ \\
\hline
\end{tabular}
est in Pamurbaya

Sources: compiled from Brander et al. (2010), Field (2008), Harahab (2010), Hoberg (2011), Suparmoko (2006), The Economics Ecosystem and Biodiversity - TEEB (2010)

\section{The Value of Timber}

Referring to Hoberg (2011) and Suparmoko (2006) the economic valuation of timber produced by the mangrove forest in this study is market price technique. This simple technique is carried out by directly observing transaction in the market that generate market price as a basis for expressing willingness to pay or willingness to pay (WTP) of individuals for goods and services (TEEB, 2010). When the natural resource has a market, the price of the item willbe 
used to calculate the gross revenue obtained by multiplying the price by the quantity. The economic value of natural resource is rent calculated by reducing total cost to the gross revenue. Therefore, the estimated economic value of timber is formulated as follows

$$
V=\left[\left(L_{U} \times Q\right)+\left(L_{T U} \times Q \times \alpha\right)\right] \times R
$$

where $\mathrm{V}$ is the economic value of timber ( $\mathrm{Rp} / \mathrm{ha} / \mathrm{year}), \mathrm{LU}$ is the total forest area (ha), LTU is the area of non-intact forest (ha), $Q$ is the timber production $\left(\mathrm{m}^{3} / \mathrm{ha}\right), \alpha$ is a constant indicating timber production in non-intact forest (\%), and $R$ is timber rent unit $\left(\mathrm{Rp} / \mathrm{m}^{3} / \mathrm{ha} /\right.$ year) which is calculated from the difference between price and average cost of wood.

In this study the values of $\alpha$ and unit rent $(R)$ are adopted from the study of Suparmoko (2006) in Kangean Island in 2001, which were 0.25 and Rp 81,600 per cubic meter (Rp/m3), respectively. The unit rent in this study (2014) was obtained through the adjustment of the 2001 value with the inflation rate in the city of Surabaya as measured by the comparison of the Consumer Price Index (CPI). By entering the inflation rate correction factor, equation (3) can be changed as follows

$$
V=\left[\left(L_{U} \times Q\right)+\left(L_{T U} \times Q \times \alpha\right)\right] \times R\left(\frac{C P I_{t}}{C P I_{0}}\right)
$$

where $\mathrm{CPI}_{\mathrm{t}}$ dan $\mathrm{CPI}_{0}$ are the Consumer Price Index in the city of Surabaya in 2014 dan 2001, respectivelly.

\section{The Value of Fisheries}

Economic valuation of fisheries uses market price techniques (Hoberg, 2011; Suparmoko, 2006) as well as the value of timber. According to Aburto-Oropeza et al. (2008), the contribution of mangrove forests to capture fish production in an area amounted to $31.7 \%$. Based on this finding, the economic value of fisheries is estimated by the following formula:

$$
V=(0,317 \times Q) \times R
$$

where $V$ is the economic value of fish (Rp/year), $Q$ is the production of fish per year (kg/year), and $R$ is rent unit of fish $(\mathrm{Rp} / \mathrm{kg})$. The price and average cost of production in this study based on BAPPEKO (2012) which is Rp 15.000,- and Rp 1,300,- per kilogram (kg), repectivelly. The prices and cost are adjusted to the inflation rate as measured by the comparison of CPI in2014 and 2011. Through this information, equation (6) can be modified as follows

$$
V=(0,137 \times Q) \times(P-C)\left(\frac{C P I_{t}}{C P I_{0}}\right)
$$

where $\mathrm{P}$ adalah the price of fish, $\mathrm{C}$ is average cost, while $\mathrm{CPI}_{t}$ dan $\mathrm{CPI}_{0}$ are the Consumer Price Index in the city of Surabaya in 2014 dan 2001, respectivelly.

\section{The Value of Outdor Recreation}

The value of the mangrove forest as outdoor recreation is estimated using the Travel Cost Method (TCM) as widely used by previous studies, such as Leong (2005) and Haridhira (2015). This valuation technique estimates WTP for using the resource as a source of amenity service based on the travel costs incurred by individuals to visit the place. Total travel cost is accumulated from transportation cost, consumption cost, documentation cost, and time costs incurred (Fauzi, 2014; Fleming and Cook, 2008).

Theoretically, by comparing the amount of the total of travel cost with the number of visits that are negatively related, the demand function for outdoor recreation will be obtained.From the demand function can be calculated consumer surplus which is a measure of outdoor recreational value (Fauzi, 2014). The demand function of ourdoor recreational services for mangrove forests is estimated using the regression model as follows 


$$
V_{i}=\beta_{0}+\beta_{1} T C_{1}
$$

where $\mathrm{Vi}$ is the number of visit of individual $\mathrm{i}$, and $\mathrm{TCi}$ is the total cost for traveling to the mangrove forest of individual i.

The number of visit is a discrete variable, so the regression model estimation for such count data is the Poison or Negative Binomial Model (University of California, Los Angeles) (UCLA, 2014). In this study, the Negative Binomial Model was used as widely applied in previous studies. Based on the regression estimation results can be calculated recreation valuel form of consumer surplus with the following formula:

$$
C S=\frac{-\sum v_{i}^{2}}{2 \beta_{1}}
$$

where CS is the consumer surplus (Rp/year), $\mathrm{Vi}=$ number of visit, and $\mathrm{b}_{1}$ is regression coefficient calculated according to equation (7).

\section{The Value of Abrasion Barier}

The economic valuation of the mangrove forest as an abrasion barrier in this study use replacement cost technique. This technique is an alternative market approach to calculate costincurred to make human product as imitations or substitutes for services provided by an ecosystem or measure the benefit obtained from replacing natural resource damage (Kaval, 2010). Referring to Suparmoko (2006) and Suzana (2011) the value is estimated based on the cost incurred for the construction of a water break and coastal protection from the danger of abrasion. The estimated cost is obtained from the professional assessment conducted by an expert. The calculation formula for abrasion barrier value of mangrove forest is as follows

$$
V=\left(L_{U} / K_{h}\right) \times T_{t} \times B_{t}
$$

where $V$ is the abrasion barrier value ( $R p / h a / y e a r), ~ L u$ is the total forest area (ha), $K_{h}$ is the thickness of the forest $(\mathrm{m}), T_{t}$ is the height of the wall $(\mathrm{m})$, and $B_{t}$ is the cost of building the wall $\left(\mathrm{Rp} / \mathrm{m}^{2}\right)$.

Some information in equation (9) is obtained from the study of Suparmoko (2006) in 2001 which stated that the forest area (L) in question is intact forest area (ha), the thickness of the forest $\left(\mathrm{K}_{\mathrm{h}}\right)$ is assumed to be 18.13 meter, the average wall height $\left(T_{t}\right)$ is 2 meters, and the cost of building a wall $\left(B_{t}\right)$ is Rp. $35,056.58$ per square meter $\left(\mathrm{m}^{2}\right)$, assuming the durability of the wall is 5 (five) years. The cost of building the wall in this study (in 2014) was obtained from adjusting these costs to the inflation rate during the period $2001-2014$, so that equation (9) becomes as follows

$$
V=\left(L_{U} / K_{h}\right) \times T_{t} \times B_{t}\left(\frac{C P I_{t}}{C P I_{0}}\right)
$$

where $\mathrm{CPI}_{\mathrm{t}}$ dan $\mathrm{CPI}_{0}$ are the Consumer Price Index in the city of Surabaya in 2014 dan 2001, respectivelly.

\section{The Value of Carbon Sinks}

The potential value of mangrove forest in the carbon sequestration process is estimated using the Transfer Benefit (BT) technique. This technique is referred to as a secondary method because the researcher uses the results of estimating the value of the primary study that has been done in a particular area (policy site) and then transfers the value to another area under study (study site) (Brander et al., 2010; Kaval, 2010). Application of BT is usually carried out when there is a problem with data collection, especially long time and very expensive costs. Calculation of BT can be divided into four categories: (1) Unit Benefit Transfer; (2) Adjusted Unit Transfer; (3) Value or Demand Function Transfer Method; and (4) Meta-AnalyticFunction 
Transfer. Taking into account the simplicity and ease of calculation, this study employs the Unit Benefit Transfer method.

This study utilizes the results of the studies by Kairo et al. (2010) and Hoberg (2011) in Kenya. According to Kairo et al. (2010) mangrove forests produce carbon benefit potential of 18 tC per ha per year, whereas according to Hoberg (2011) carbon price is US\$ 7/ton. In this study, the carbon price will be adjusted through involving some relevan information: (1) the purchasing power parity ratio between Indonesia and Kenya (measured by the value of Gross Domestic Product in 2010) to correct the differences in the purchasing power of the two countries; (2) the exchange rate in 2010 to convert the unit of value from dollars (S) to rupiah (Rp); dan (3) the inflation rate from 2010 to 2014. The carbon price estimated after these adjustments is formulated as follows

$$
P_{I}=P_{k} \times\left(\frac{G D P_{I}}{G D P_{K}}\right) \times E R \times\left(\frac{C P I_{t}}{C P I_{0}}\right)
$$

where $P_{I}$ is the price of carbon in Indonesia, $P_{K}$ is the price of carbon in Kenya, GDP and GDP are the values of the Gross Domestic Product of Indonesia and Kenya (in US \$), respectively, at 2001 constant price, ER is the exchange rate Rupiah (Rp) per US Dollar (US \$) in 2001, and CPI and $\mathrm{CPI}_{0}$ are the Consumer Price Index in the city of Surabaya in 2014 and 2001 respectivelly.

\section{The Value of Biodiversity}

The value of biodiversity of mangrove forest is also estimated using the BT technique. In this study, biodiversity prices adopted the results of the study of Ruitenbeek (1991) in Irian Jaya in 1990, which was valued at US $\$ 1,500$ per $\mathrm{km}^{2}$ or US $\$ 15$ per ha per year. Because of the location of the study in Indonesia, there is no need to adjust purchasing power. The adjustments only involve the exchange rate in 1990 and the inflation rate from 1990 to 2014 . The biodiversity value is estimated by formula as follows:

$$
V_{S}=V_{j} \times E R \times\left(\frac{C P I_{t}}{C P I_{0}}\right)
$$

where $\mathrm{Vs}$ is the biodiversity value ( $\mathrm{Rp} / \mathrm{ha}), \mathrm{Vj}$ is the biodiversity value in Irian Jaya (US\$/ha), and $\mathrm{CPI}_{\mathrm{t}}$ and $\mathrm{CPI}_{0}$ are the Consumer Prices Index in 2014 and 1990, respectively.

\section{The Non-use Value}

Non-use values, consisting of bequest value and existence value, are intangible intrinsic values (Hoberg, 2011; Kaval, 2010). The valuation technique commonly used for this type of value is the Contingent Valuation Method (CVM). This technique estimates individual WTP directly based on certain hypothetical scenarios. The WTP offer can be done using several types of elicitation methods. One of them that is often used and will be used in this study is bidding games. This method starts by offering an initial bid and then the value is raised repeatedly until the respondent answers "no" (Fauzi, 2014). The non-use values are estimated using the following formula

$$
\sum W T P=W T P \times \alpha \times N
$$

where WTP is the average of the individual WTP, $\alpha$ is the percentage of respondents who are willing to pay more, and $\mathrm{N}$ is the number of visitors to the mangrove forests in one year.

\section{Result and Discussion}

The result of the total economic valuae of the mangrove forest in the East Coast of the city of Surabaya (Pamurbaya) is presented in Table 2 . To facilitate the comparison between the various components of the economic value of the mangrove forests and other similar studies, these values are stated in IDR per ha per year.

The total economic value (TEV) of the mangrove forests in Pamurbaya is around Rp 
49.6 billion (US\$ 3.8 million) per year or 105.3 million (US\$ 8,101.8) per ha per year. This value is almost six times higher than the estimation conducted by BAPPEKO Surabaya (2012) in the same location in 2011, which is around Rp 19 million per ha per year. In addition, the result of this study is also relatively higher compared to similar studies located in Indonesia, such as Ruitenbeek (1991) in Irian Jaya (US\$ 212 per ha per year); Harahab (2010) in Kecamatan Gending, Kabupaten Probolinggo (Rp 95.5 million per ha per year); Suzana et al. (2011) in Desa Palaes, Kecamatan Likupang Barat, Kabupaten North Minahasa (Rp 10.9 billion per year); and Haridhira (2012) in Benoa Bay, Bali (Rp 7 million per ha per year). However, whencompared to the studies conducted in other countries, the estimation result in this study is at amoderate rate, which is higher than Hoberg (2011) in Kenya (US \$1,092.3), but lower than Leong (2005) in Kuala Selangor, Malaysia (US \$ 61,357) and Sathirathai \& Barbier (2001) inSouthern Thailand (US $\$ 27,264-35,921$ per ha per year). The variation in the estimation results is a common phenomenon in the study of the economic valuation of natural resource like the mangrove forest because the geographical conditions of different regions will producediversity and uniqueness in their natural resources. In addition, technically the results of economic valuations are influenced by many factors, especially the types of value studied, valuation and measurement methods, and data used.

Table : Total Economic Value of the Mangrove Forest di Pamurbaya

\begin{tabular}{|c|c|c|}
\hline Types of Value & Ecomic Value( Rp/ha/year) & $\begin{array}{c}\text { Proportion to } \\
\text { Total (\%) }\end{array}$ \\
\hline Use Value (UV) & $105,077,349.80$ & 99.77 \\
\hline Direct Use Value (DUV) & $94,574,890.60$ & 89.80 \\
\hline The value of timber & $4,878,447.55^{a}$ & 4.63 \\
\hline The value of fisheries & $80,569,525.80^{b}$ & 76.50 \\
\hline The value of outdoor recreation & $9,126,917.24^{c}$ & 8.67 \\
\hline Indirect Use Value (IUV) & $10,217,578.59$ & 9.70 \\
\hline The value of abrasion barrier & $4,587,552.92^{d}$ & 4.36 \\
\hline The value of carbon sinks & $5,630,025.67^{e}$ & 5.35 \\
\hline Option Value (OV) & $284,880.61$ & 0.27 \\
\hline The value of biodiversity & $284,880.61^{f}$ & 0.27 \\
\hline Non-use Value (NUV) & $245,606.64$ & 0.23 \\
\hline Bequest value and existence value & $245,606.64^{\mathrm{g}}$ & 0.23 \\
\hline Total Economic Value & $105,322,956.44$ & 100.0 \\
\hline
\end{tabular}

Source: Estimation result

Notes:
a. Equation (4): $\mathrm{LU}=112.13 ; \mathrm{LTU}=359.02 ; \mathrm{Q}=56 ; \mathrm{CPI}=151.56 ; \mathrm{CPI} 0=60.83$
b. Equation (6): $\mathrm{Q}=7,292,730 ; \mathrm{CPI}=151.56 ; \mathrm{CPIO}=126.45$
c. Equation (8): $\mathrm{Vi}_{\mathbf{i}}=171 ; \mathrm{b} 1=-0.0000034$
d. Equation (10): $\mathrm{LU}=112.13 ; \mathrm{CPIt}=151.56 ; \mathrm{CPIO}=60.83$
e. Equation (11): $\mathrm{GDPI}=7,872 ; \mathrm{GDPK}=2,040 ; \mathrm{ER}=9,090.43 ; \mathrm{CPIt}=151.56 ; \mathrm{CPIO}=118.99$
f. Equation (12): $\mathrm{ER}=1,842.81 ; \mathrm{CPIt}=151.56 ; \mathrm{CPIO}=14.71$
g. Equation 13): $\mathrm{WTP}=40,384.62 ; \mathrm{a}=0.12 ; \mathrm{N}=24,466$

Almost all (99.77\%) of the total economic value of the mangrove forests in Pamurbaya is use value (UV), and the rest (0.23\%) is non-use value (NUV). The low non-use value is mainly due to the characteristics of these types of value that are intangible, so it is relatively difficult to measure compared to use values. The valuation technique that is relevant and widelyused in various studies for this type of value is CVM through primary data surveys. The magnitude of the non-use value (measured by WTP) is largely determined by the respondents'perceptions 
to the condition of the current research object. The results of interviews with 111 respondents who visited the mangrove forest tourism park as samples showed that their assessment of the condition of mangrove forest in Pamurbaya was relatively low. The averagescore is 5.8 (scale 1 - 10) which included aspects of cleanliness, safety, facilities, accessibility, service and availability of information. In consequence, it is around $88 \%$ of the respondents are not willing to pay more than the applicable ticket price. This fact is expressed by the value $\alpha$ of 0.12 in equation (13), so that mathematically it will produce a very low estimated value.

The use value (UV) consists of three component; those are direct use (DUV), indirect use value (IUV), and option value (OV) with each contribution to TEV is $89.8 \%$; $9.70 \%$; and $0.27 \%$, respectivelly. The dominance of direct use value shows that the mangrove forests in Pamurbaya is widely used economically by the local community, both extractive benefit in theform of timber and fisheries as well as non-extractive benefit as a place of outdoor recreation or eco-tourism. Although around $46 \%$ of respondents know the function of mangrove forests as abrasion barier and carbon sinks, those ecological functions are long-term and usually these benefits are highly valued when the function decreases. Therefore, individual preferences for ecological benefits (IUV) of mangrove forests are generally lower than the economic benefits (DUV). The smallest contribution of direct use value is option value (OV) as measured by biodiversity value. This result confirms Ruitenbeek (1992) that the biodiversity value of mangrove forest is relatively small, which is about half of tropical rainforest. This fact is also proved by the results of interview that less than $4 \%$ of visitors who use mangrove forests in Pamurabaya for educational and research purposes.

The value of fisheries makes the biggest contribution not only to direct use value (around $85 \%$ ), but also to total economic value (around $77 \%$ ). The result is in line with the findings of Harahab (2010), Ruitenbeek (1992), and Sathirathai and Barbier (2001). The fishery value is obtained from the function of the mangrove forests as a feeding ground, spawning ground, andnursery ground for fish larvae and other marine biota (Harahab, 2010; Stewart and Fairfull, 2008). In fact, along the Pamurbaya has been used as fishing areas by the local community fora long time, so many of them work as fishermen.

Although timber has the same type of economic value as fisheries, as extractive natural resource, but the contribution of timber value is very small (less than $5 \%$ of TEV) because of two main arguments as follows. First, the total area of mangrove forest is only 112.13 ha from 471.15 ha (around $24 \%$ ) of the total area, so that the resulting timber production is low. Second, since 2007 the mangrove forest in Pamurbaya has been used as conservation areas, so that thelocal community only uses timber (especially wood) in the form of dead branches as fuel for cooking or processing them into charcoal.

Meanwhile, the direct non-extractive use value of the mangrove forest can be derived from ourdoor recreational value. The estimation results using TCM techniques from 111 respondents who visited the mangrove ecotourism area produced the recreational value (measured by consumer surplus) of around Rp 4.3 billion or Rp. 9.1 million per ha per year. This value is greater than the similar study in Benoa Bay, Bali Province which was valued at $\mathrm{Rp}$ 2.6 million per ha per year (Haridhira, 2012). Although it is much lower than the value of the fishery, the recreation value is higher than the value of timber. The data recommends that the mangrove forest in Pamurbaya be more valuable if they are used as natural attractions (conservation benefit) rather than being cut down (exploitation benefit).

Based on equation (8) the recreation value is determined by two factors; those are the frequency of visits and the travel costs. The interview result showed that the majority (around 73\%) of respondents visited the mangrove forest ecotourism area only once. Most of them (around 64\%) obtained the information of the mangrove forest from friends or family. All visitors (100\%) come from Surabaya with an average distance of less than $25 \mathrm{~km}$ and the visiting time is relatively short, which is about 3 hours on average. The implication of these facts is that the travel cost incurred towards the location is very small; that is on average less than Rp 
100,000 . Besides producing relatively small recreational values, this finding indicatesthat the mangrove ecotourism area is still a local scale, unknown to the wider community outside the city of Surabaya, and not yet having the attraction to visit.

The outdoor recreational value can be used to evaluate ticket price to enter the mangroveecotourism area in Pamurbaya. Data from Dinas Pertanian Kota Surabaya states that the price of admission for adults is IDR 25 thousand and children IDR 15,000. The receipt of the management from the ticket sales results is $\mathrm{Rp} 564,400,000$ per year on average. With the number of visitors in 2014 as many as 24,466 , the ticket price obtained from estimated model is around $\mathrm{Rp} 28$ thousand on average. Meanwhile, with a recreation value of around $\mathrm{Rp} 4.3$ billion, the recreation value per visitor is around $\mathrm{Rp} 175$ thousand. This means that the current price of admission is only around one-sixth of the value that should be paid by visitors. Thisfact proves that in the case of natural and environmental resources, market prices generally estimate undervalued and do not reflect true economic value.

\section{Conclusssion}

The economic valuation of mangrove forests in the East Coast of city of Surabaya (Pamurbaya) involving several valuation techniques produces a total economic value of around Rp.49.6 billion (US\$3.8 million) per year or 105.3 million (US $\$ 8,101.8$ ) per ha per year. Almost all of these values are use values, especially direct use value, both extractive (timber and fisheries) and non-extractive (outdoor recreation). The indirect use value which consists ofthe value of abrasion barrier and carbon sinks contributed relatively little compared to direct use value. This fact indicates that the mangrove forest in Pamurbaya provides more economicbenefits than ecological benefits. The non-use value which is intangible and difficult to measure gives the smallest contribution to the total economic value.

This study also confirms that market prices have a tendency to produce underestimate value of natural resource and environmental and do not reflect true economic value. This phenomenon is proved by the price of ticket entering the mangrove ecotourism area is only about one-sixth of the recreation value per visitor.

Conservation of mangrove forests (and other natural resources) involves the analysis of benefits and costs as the basis for decisions and policy evaluations. The results of the economic valuation of mangrove forests in this study only estimate the benefits aspect. While in terms ofcost, to overcome limited funds and increase community participation, demand-driven policiesare needed. In an effort to implement this policy, this study recommends a study of willingnessto pay for the conservation of mangrove forests on the East Coast of Surabaya.

\section{References}

Aburto-Oropeza O., Ezcurra E., Danemann G., Valdez V., Murray J., dan Sala E. 2008. Mangroves in the Gulf of California increase fishery yealds. PNAS, 105 (30): 10456- 10459.

Badan Lingkungan Hidup Kota Surabaya. (2012). Profil Keanekaragaman Hayati Kota Surabaya. https://lh.surabaya.go.id/weblh/

BAPPEKO Surabaya. (2012). Kajian Sosial Ekonomi Pemberdayaan Masyarakat di Kawasan Konservasi Surabaya.

Brander, L., Gómez-Baggethun, E., Martín-López, B., \& Verma, M. (2010). The economics of valuing ecosystem services and biodiversity: Ecological and economic foundations. In The economics of valuing ecosystem services and biodiversity (Issue March).

Fauzi, A. 2014. Valuasi Ekonomi dan Penilaian Kerusakan Sumber Daya Alam dan Lingkungan. Bogor: IPB Press.

Fleming, C. M., and Averil C. (2008). The Recreational value of Lake McKenzie, Fraser Island: An Application of The Travel Cost Method. Tourism Management, 29 (2) 1197-1205. 
Harahab, N. (2010). Penilaian Ekonomi Ekosistem Hutan Mangrove \& Aplikasinya dalam Perencanaan Wilayah Pesisir (1st ed.). Graha Ilmu.

Haridhira, I. G. N. A. (2012). Valuasi Nilai Ekonomi Total Kawasan Hutan Mangrove Taman Hutan Raya Ngurah Rai Di Sepanjang Teluk Benoa, Provinsi Bali (Doctoral dissertation, Universitas Gadjah Mada).

Hoberg, J. (2011). Economic Analysis of Mangrove Forests: A Case Study in Gazi Bay, Kenya. United Nations Environment Programme.

Kairo, J., Wanjiru, C., and Ochiewo, J. (2009). Economic Analysis of Mangrove Forests: A case study in Gazi Bay. In Journal of Sustainable Forestry (Vol. 28).

Kementerian Lingkungan Hidup. (2012). Peraturan Menteri Negara Lingkungan Hidup Nomor 5 Tentang Panduan Valuasi Ekonomi Ekosistem Hutan. Jakarta.

Leong, L. F., Kwan, K. K., Chong, V. C., \& Sasekumar, A. (2005). Resource valuation of Kuala Selangor mangrove forest. University of Malaya Press.

Kaval, P. (2010). A Summary of Ecosystem Service Economic Valuation Methods and Recommendations for Future Studies. In University of Waikato (Vol. 64, Issue 7).

Pemerintah Provinsi Jawa Timur. (2013). ASEAN Pilih Surabaya Jadi Percontohan Mangrove. www.jatimprov.go.id

Ruitenbeek, H. J. (1991). Mangrove management: an economic analysis of management options with a focus on Bintuni Bay, Irian Jaya. School for Resource and Environmental Studies, Dalhousie University.

Sathirathai, S., \& Barbier, E. B. (2001). Valuing mangrove conservation in southern Thailand. Contemporary economic policy, 19(2), 109-122.

Stewart, M., \& Fairfull, S. (2008). Mangroves. IN INDUSTRIES, NDOP (Ed.). Sydney, NSW Goverment.

Suparmoko, M. (2005). Neraca Sumberdaya Alam (Natural Resource Accounting). Yogyakarta: BPFE.

Sugiyono. (2012). Metode Penelitian Kuantitatif Kualitatif dan R\&D. Bandung: Alfabeta.

Suzana, B. O. L., Timban, J., Kaunang, R., \& Ahmad, F. (2011). Valuasi Ekonomi Sumberdaya Hutan Mangrove Di Desa Palaes Kecamatan Likupang Barat Kabupaten Minahasa Utara. Agri-Sosioekonomi, 7(2). https://doi.org/10.35791/agrsosek.7.2.2011.89

The Economics Ecosystem and Biodiversity. (2010). The Economics of Ecosystem and Biodiversity for Local and Regional Policy Makers. Malta: Progress Press.

University of California, Los Angeles. (2014). Data Analysis Examples, Stata Data Analysis Examples Negative Binomial Regression, (Online),www.ats.ucla.edu/stat/stata/dae/ nbreg.htm, accessed on Agustus 2, 2014.

Vo, Q. T., Kuenzer, C., Vo, Q. M., Moder, F., \& Oppelt, N. (2012). Review of valuation methods for mangrove ecosystem services. In Ecological Indicators (Vol. 23). https://doi. org/10.1016/j.ecolind.2012.04.022 